IRSH 53 (2008), pp. 26I-292 DOI: I0.10I7/S002085900800344I

(C) 2008 Internationaal Instituut voor Sociale Geschiedenis

\title{
The i9i I Waterfront Strikes in Glasgow: Trade Unions and Rank-and-File Militancy in the Labour Unrest of I9I0-I914*
}

\author{
MatT VAughan WiLs ON
}

Summary: This article examines one of several massive industrial conflicts experienced in Britain and elsewhere during I910-19I4, paying particular attention to organization and the dynamics of the strikes at a local level. It takes as a case study the port of Glasgow, which has until recently received little attention from historians of waterfront labour, despite its status as a major port and an important area for labour activity. Much literature on the waterfront strike wave emphasizes spontaneity and rank-and-file initiative. These were important in Glasgow as elsewhere, but experiences varied markedly between the major ports. Moreover, prior organization and individual initiative should not be overlooked. Officials of the National Sailors' and Firemen's Union played a significant role at national and international levels, while Glasgow Trades Council and activists associated with it provided a critical lead locally. The strongly local character of the strike movement and its leadership in Glasgow shaped both the strikes themselves - which were appreciably more unified and coherent in Glasgow than in some other centres - and the subsequent development of waterfront organization on the Clyde, marked as it was by the emergence of independent locally-based unions among both dockers and seamen.

In the summer of I9I I, strikes took place among seafarers and dockers in all the major British ports, in Belgium, the Netherlands and parts of the USA. These were perhaps the first strikes organized on an international

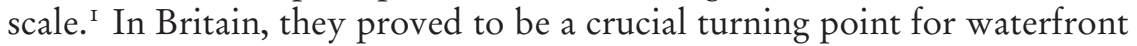
trade unionism, for they enabled dockers' and seamen's unions to surpass the peak membership levels they had established during the earlier upsurge

\footnotetext{
* I would like to thank Adrian Randall, the Editors, and two anonymous referees for the journal for helpful comments on earlier drafts, and to acknowledge the financial assistance of the Arts and Humanities Research Council, which funded the research on which this article is based. An early draft was presented at a conference on "The History of Strikes, Lock-Outs and General Strikes", organized by the Society for the Study of Labour History and Historical Studies in Industrial Relations and held at Keele University, UK in May 2006.

I. Marcel van der Linden, "Transport Workers' Strike, Worldwide I9 I I", in Neil Schlager (ed.), St. James Encyclopedia of Labor History Worldwide: Major Events in Labor History and Their Impact, 2 vols (Detroit, MI, 2003), II, pp. 334-336.
} 
of I 888-I893, and to obtain recognition from the majority of employers, which they had never previously enjoyed. In the British context, the waterfront strikes were also a key episode in the r9io-i9i4 "labour unrest", which saw a large increase in overall levels of strike activity and strikes on an unprecedented scale in a number of major industries including coal mining, textiles, and transport.

What made this period of unrest remarkable was not simply the scale of industrial conflict witnessed but the manner in which many strikes developed. They spread rapidly and unpredictably between different areas and sections of industry, in some cases generating rank-and-file challenges to existing union leaderships. Sympathetic stoppages and direct action by the rank and file were conspicuous features of industrial conflict in this period generally, and have often been emphasized as aspects of particular episodes. ${ }^{2}$ The strikes at the waterfront in I9I I, for example, have been presented as a largely spontaneous upsurge of rank-and-file militancy, mediated with some difficulty by union leaders. ${ }^{3}$

The dynamics of this strike wave were complex, however. Holton points to the "unofficial dynamic" of the strike wave but also to the propaganda work carried out by various union leaders in advance of the strikes, concluding that "the subsequent outbreak of militant strike action [...] was not as sudden or 'spontaneous' as it might seem". ${ }^{4}$ Similarly, Ken Coates and Tony Topham seek to balance recognition of the role played by local activists and waterfront rank and file against an appreciation of the "vigorous national lead" provided by such well-known figures as Tom Mann and the seamen's leader, Havelock Wilson.5 There are important questions to be addressed here about the role played by the various agencies involved in the outbreak and development of the strikes, and about the character of the conflict. Such questions need to be approached from the perspective of the whole movement at the waterfront, rather than that of the individual groups involved. ${ }^{6}$

2. A useful overview of historical approaches is Joe White, "I910-I9I4 Reconsidered", in James

E. Cronin and Jonathan Schneer (eds), Social Conflict and the Political Order in Modern Britain (London, 1982), pp. 73-95; Roy Church, "Edwardian Labour Unrest and Coalfield Militancy, I890-1914", The Historical Journal, 30 (1987), pp. 84I-857, offers a contrasting review.

3. Some examples include James Hinton, Labour and Socialism (Brighton, 1983), pp. 86-89; Keith Burgess, The Challenge of Labour (London, I980), pp I36-138; Bob Holton, British Syndicalism: Myths and Realities (London, 1976), pp. 89-1 10.

4. Ibid., p. 93.

5. Ken Coates and Tony Topham, The Making of the Labour Movement: The Formation of the Transport \& General Workers' Union, I870-1922 (Nottingham, 1994), pp. 342-343.

6. Studies of waterfront labour with material on the events of I9I I include Eric Taplin, The Dockers' Union: A Study of the National Union of Dock Labourers, I889-I922 (Leicester, 1985 ); John Lovell, Stevedores and Dockers: A Study of Trade Unionism in the Port of London, I8701914 (London, I969); M.J. Daunton, "Inter-Union Relations on the Waterfront: Cardiff i 888 I914", International Review of Social History, 22 (1977), pp. 350-378; P.J. Leng, The Welsh Dockers (Ormskirk, I98I). Two studies of the waterfront strikes and other subsequent conflicts 
This article re-examines the waterfront strikes primarily from the perspective of developments in the port of Glasgow. Located at the centre of the heavily populated and industrialized Clydeside region, and employing more than I5,000 seafarers and dockers, Glasgow was prominent among the United Kingdom's major ports in the early twentieth century. Until recently, this has not been well reflected in historical work on Clydeside labour, the focus of which has often been on skilled groups in shipbuilding and engineering, which were of even greater significance locally, and on the events of World War I and its immediate aftermath - the period of "Red Clydeside". This has begun to change in recent years. William Kenefick's research on Glasgow dockers has underlined the significance of dock labour within Glasgow and the significance of Glasgow's experiences for our understanding of broader trends in dock labour and trade unionism. ${ }^{7}$ In addition, a number of scholars have investigated the events of I9IO-I9I4 in the west of Scotland, exploring the relationship between the militancy of those years and the events of the Red Clydeside period that followed. ${ }^{8}$ Despite this, a broad phenomenon such as the I9II waterfront strikes continues to be seen largely from the perspective of Liverpool, Hull, or Cardiff, whose experiences over that summer have been tracked in more detail and are better known.

Like the ports noted above, Glasgow witnessed impressive displays of militancy and solidarity over the summer of I9II. Glasgow had its peculiarities, however, such as the extremely proactive role played by the Trades Council in preparing for and directing action at waterfront, and the position of Glasgow's dockers, who were not integrated into any existing trade union when the strikes began. The centrality of local leaders and institutions may explain why the movement in Glasgow remained somewhat more cohesive than in other ports, as seems to have been the case. We can discern a great deal of independent rank-and-file action at Glasgow's waterfront, but little of the tension and occasional overt conflict that marked the relationship between strikers and strike leaders in some other ports.

The centrality of local forces also had significant repercussions in the longer term, as it contributed to a pronounced preference for independent

are K. Brooker, The Hull Strikes of I9I I (Beverley, I979), and Eric Taplin, Near to Revolution: the Liverpool General Transport Strike I9I I (Liverpool, 1994).

7. William Kenefick, Rebellious and Contrary: The Glasgow Dockers, $1853-1932$ (Tuckwell, 2000); idem, "A Struggle for Control: The Importance of the Great Unrest at Glasgow Harbour, I9I I to I91 2", in William Kenefick and Arthur McIvor (eds), The Roots of Red Clydeside I9I0I4?: Labour Unrest and Industrial Relations in West Scotland (Edinburgh, 1996), pp. I 29- I 52; idem, "A Struggle for Recognition and Independence: The Growth and Development of Dock Unionism at the Port of Glasgow, c.1853-1932", in Sam Davies et al., Dock Workers: International Explorations in Comparative Labour History, 2 vols (Aldershot, 2000), pp. 319-34I.

8. Kenefick and McIvor, Roots of Red Clydeside?. 
locally-based organization among both dockers and seamen, which became a conspicuous feature of Glasgow in the period that followed. In these respects, the waterfront strikes developed very much in a specific local context and fostered peculiar local lines of development. But these events were also part of a much broader phenomenon. By examining the situation in Glasgow, it is possible to shed new light on the background to the strikes, including trade-union-led preparations at a national and international level, and on important factors contributing to the widespread extension and general success of the strike movement as a whole.

\section{THE NSFU AND THE INTERNATIONAL SEAMEN'S STRIKE CAMPAIGN}

The waterfront strike wave began in earnest on I 4 June, when the National Sailors' and Firemen's Union (NSFU) declared a seamen's strike throughout Britain and Ireland. It has been suggested that this declaration was a hasty response to burgeoning unrest at the grassroots. ${ }^{9}$ In fact, preparations for mass action on a very broad scale had long been underway. Before turning to Glasgow, we must consider the nature and extent of these preparations, along with the general position of waterfront labour in the period leading up to I9I I. The NSFU emerged in the late i 880 s, alongside mass unions of dockers and other similarly "unskilled" and hitherto poorly organized groups. The London Dock Strike of i 889 symbolized the rapid growth and impressive gains achieved by these new unions. However, their progress was soon checked after this point, as economic conditions became less propitious and employers' efforts to resist the unions became more sophisticated and determined. The Shipping Federation was established in I 890 as a means of coordinating strikebreaking and other anti-union initiatives, in which it proved very effective. ${ }^{10}$ Several serious industrial defeats were inflicted during I891-I893, which enormously depleted the resources and influence of the new maritime unions. ${ }^{\text {I I }}$

9. In particular, it has been suggested that the outbreak of sailors' and dockers' strikes in Southampton in the first two weeks of June prompted a hesitant Seamen's Union into action. F.J. Lindop concludes that the Southampton strike "galvanised a rather uncertain Wilson into action", in "The History of Merchant Seamen's Trade Unionism”, (unpublished M.Phil. thesis, University of London, I972), p. 40. Jonathan Schneer puts forward a similar view in Ben Tillett: Portrait of a Labour Leader (London, I982), p. I 52.

I0. L.H. Powell, The Shipping Federation: The First Sixty Years, I890-1959 (London, I960); John Saville, "Trade Unions and Free Labour: The Background to the Taff Vale Decision", in Asa Briggs and John Saville (eds), Essays in Labour History (London, 1967, 2nd edn), pp. 317-350.

I I. Particularly damaging defeats were registered at Cardiff in I89i and Bristol and Hull in I892-I893. See Daunton, "Inter-Union Relations on the Waterfront"; Raymond Brown, Waterfront Organisation in Hull, I870-1900 (Hull, 1972); Coates and Topham, Making of the Labour Movement, pp. I54-165. 
The dockers' unions were able to preserve substantial pockets of employer recognition and high membership in particular localities, notably the south end of Liverpool Docks in the case of the National Union of Dock Labourers (NUDL), and the ports of South Wales, with the important exception of Cardiff, in the case of the Dock, Wharf, Riverside, and General Labourers' Union (DWRGLU). ${ }^{\mathrm{I} 2}$ The seamen's union had much less success in this regard, in addition to which it experienced enormous financial difficulties, which made it both weaker and less stable than its shore-based counterparts. All these unions remained active, however, thus providing an existing foundation on which to base efforts to re-establish trade-union strength. Among the dockers, the basis of organization was often local, regional, or sectional. This was much less the case among seamen, as the NSFU faced few significant competitors, and was in this sense much better placed than the dockers' unions to conduct a nationwide campaign. ${ }^{\mathrm{I}}$

Mass strikes and trade-union growth were features of many countries besides Britain in the above period. ${ }^{14}$ The international character of the shipping industry promoted connections across national boundaries, which began to be consolidated during the I890s, partly through the efforts of British leaders. The NSFU developed a network of overseas branches in the I890s, seeking both to serve British members and to recruit seamen of other nationalities. Additionally, its president, Havelock Wilson, played a prominent role, alongside fellow maritime organizers Ben Tillett and Tom Mann, in forming the International Transport Workers' Federation (ITF) in I 896. ${ }^{\text {Is }}$ The latter provided a permanent forum for communication and collaborative activity among maritime and transport unions, and played a key role in the development of plans for international strike action in $\mathrm{I} 9 \mathrm{I} \mathrm{I}^{\mathrm{I}}{ }^{\mathrm{6}}$

Maritime employers somewhat belatedly followed the unions' lead, and in 1909 formed the International Shipping Federation, which linked

I 2. Leng, The Welsh Dockers; Taplin, The Dockers' Union. On the importance of such footholds see E.J. Hobsbawm, "General Labour Unions in Britain, I889-1914", in idem, Labouring Men: Studies in the History of Labour (London, 1964), pp. 179-203, I87-189; John Lovell, "Sail, Steam and Emergent Dockers' Unionism in Britain, I $850-1914$ ", International Review of Social History, 32 (1987), pp. 230-249.

I3. The only local seamen's unions of any significance were in Hull and Sunderland. An overview of trade unions among seamen and dockers can be found in A. Marsh and V. Ryan, Historical Directory of Trade Unions, III (Gower, 1987).

I4. Frank Broeze, "Militancy and Pragmatism: An International Perspective on Maritime Labour, I870-1914", International Review of Social History, 36 (1991), pp. 165-200.

I s. Tillett was founder and president of the DWRGLU. Mann was active in this union and also in the NSFU, of which he was an honorary official.

16. Coates and Topham, Making of the Labour Movement, pp. 169-174, K.A. Golding, "International Transport Workers" (unpublished manuscript history of the ITF), Modern Records Centre, University of Warwick [hereafter MRC], MSS.I 59/4/526, pp. 8-i I. 
national ship-owner associations in Britain, Germany, Sweden, Denmark, and Belgium. ${ }^{17}$ This development took place amid a pronounced slump in shipping, and was greeted by the unions as an omen of impending attack, a subject much discussed at the ITF's I908 biannual conference. ${ }^{\mathrm{I} 8}$ During 1909-I910, however, trade and employment levels improved and the leaders of several seamen's unions, most notably Andrew Furuseth of the International Seamen's Union of America (ISUA) and Havelock Wilson of the British NSFU, began actively considering the possibility of an aggressive campaign. ${ }^{19}$

This was the background to proposals for an international seamen's strike which were discussed at the ITF's biannual congress in August I9I0 and attracted support from Scandinavian, Belgian, and Dutch unions as well as the British contingent. ${ }^{20}$ To follow this up, an international seamen's conference was held at Antwerp in November I910 and an International Strike Committee was established under the chairmanship of the NSFU's Father Charles Hopkins to take preparations forward. ${ }^{21} \mathrm{~A}$ final international meeting took place in London on I May I9I I, at which action was fixed for Britain, Belgium, and the Netherlands. It has been said that the international movement rapidly collapsed in the summer of I9I I, leaving British seamen to face the ship-owners alone. ${ }^{22}$ This was not quite the case, for although the Scandinavian countries did not ultimately take part, there were significant stoppages in Belgium and the Netherlands as well as sympathetic action by dockers at German ports. ${ }^{23}$ The immediate significance of these stoppages varied from port to port according to proximity and trading connections. Glasgow, in the northwest, was not greatly affected by the situation in Antwerp, Rotterdam, or Hamburg, but looked principally to Irish and west coast ports for solidarity. But London and the east coast ports were in a different position and benefited much more directly by the actions of dockers and seamen in continental ports.

In parallel with the international efforts outlined above, the NSFU pursued a vigorous domestic campaign of propaganda and organization. This began in July I9I0, a month before the ITF considered the strike

17. The Times, 26 October 1909; Golding, "International Transport Workers", p. 92.

I8. Minutes of the 1908 and I9Io conferences are available (in German) MRC, MSS.I59/I/I/ 5-7. Additional material includes a survey carried out by the ITF on the membership, resources, and activity of affiliated seamen's unions, in preparation for the strikes.

19. Golding, "International Transport Workers", pp. I09-I25, Van der Linden, "Transport Workers' Strike”; Hyman Weintraub, Andrew Furuseth: Emancipator of the Seamen, (Berkeley, CA, 1959), p. 99.

20. The following account draws primarily on Golding, "International Transport Workers".

21. "Report of an international conference held at Antwerp, I2-I4 March I9II", MRC, MSS. $175 / 7 / \mathrm{HIST} / 2$.

22. Daunton, "Inter-Union Relations on the Waterfront", p. 368.

23. Van der Linden, "Transport Workers, Worldwide". 
scheme, with a round of mass meetings in all the major ports. ${ }^{24} \mathrm{~A}$ second wave of meetings followed in January and February I9I I. Glasgow hosted one mass meeting in July I9IO and two in January I9I I. ${ }^{25}$ Such meetings were well attended in themselves and their content reached wider audiences through coverage in national and local newspapers, which was extensive, above all in the major ports. In addition, the NSFU periodically despatched delegations to the Board of Trade, issued appeals to the Shipping Federation, and briefed reporters on its progress and intentions, achieving considerable success in its efforts to publicize the campaign.

The programme of demands that the NSFU presented during this period was less dramatic in itself than the method proposed to advance it. Several points concerned longstanding industrial grievances such as manning scales and quality of food and accommodation. On wages, the Union called for standard rates but not explicitly for increases, its main concern being to even out local disparities and ease the way for a transition from local to national wage-bargaining. The need to curb the power of shipowners in employment matters was emphasized. ${ }^{26}$ The overarching concern was to secure union recognition and a basis for collective bargaining, which NSFU leaders equated with the establishment of Conciliation Boards and sometimes linked to proposals for a "sliding scale" linking wages to freight levels. ${ }^{27}$ Conciliation Boards soon became identified as the campaign's central demand, though this ceased to be the case once the strikes actually got underway in the summer of I9I I.

The activities outlined above made a real contribution to developing rank-and-file confidence and enthusiasm for strike action. Yet the weaknesses of the union's position imposed a great many limitations on its leaders' ability to prepare for industrial conflict. Membership levels were very low in the years preceding the strikes, and although its campaign work gave a boost to membership, the extent and durability of the union's progress remained uncertain. ${ }^{28}$ In February i9I I, Wilson told Jochade of

24. The Times, 2 I June I910; 9, I0 and I 2 July I 9 I0. The NSFU was also actively campaigning around this time in Antwerp and Rotterdam, where a great many British seafarers were signed on and off ships; J.H. Wilson to H. Jochade, I7 July I910, MRC, MSS. I59/3/63/I.

25. Southampton Times, 23 July and I 3 August i9ro; Glasgow Herald, 2 I July I 910 and 16 January I9I I; Glasgow Trades Council Minutes, i 8 January I9I I.

26. Special objections were raised to the practice of subjecting seamen to medical inspection by doctors employed by the Shipping Federation, alleged to be a cover for victimization, and the engagement of crews in Federation offices rather than in "neutral" venues such as Board of Trade offices or on board ship.

27. Glasgow Herald, report of meetings in Poplar and Glasgow, i 8 and 2 I July i9 10; Report of deputation to Board of Trade, 29 July 19ro; Southampton Times, 23 August 19ro; The Times, 9 July ír iо.

28. In I $908-1910$, the Union had registered memberships of 9,000, 10,000 and I 2,000, far below the peak figure of 60,000 recorded in I889-1890, and a small fraction of the overall workforce, 
the ITF that the union had enrolled over 35,000 members in the preceding eighteen months, but stressed that most were

$[\ldots]$ in arrears with their payments, because they say "What is the good of paying up unless you know that the Union is going to do something?”. It is only by a big agitation that we hope to get these men to pay up their arrears, and get a large number of other men to join. ${ }^{29}$

This goes some long way to explaining the leadership's enthusiasm for a major industrial conflict.

Finance continued to be among the union's most conspicuous weaknesses, partly because of the special expenses and difficulties it faced as a union catering for seamen. ${ }^{30}$ It was still several thousand pounds in debt when the strikes began and was therefore in no position to provide strike pay out of existing funds. ${ }^{3}$ The hope seems to have been that contributions from seamen who achieved early victories and rushed to join the union would provide funds to support others who faced stiffer resistance. A further complication was the shortage of experienced leaders within the union's own ranks. At a local level, the union often had to rely on the broader labour movement to provide an adequate leadership for the contemplated strike. This was certainly the case in Glasgow, where delegates coopted from the Trades Council played a central role in planning and directing the local movement, alongside activists drawn from the rank and file. However, trades councils in some other ports, such as Hull, refused to offer more than moral support. ${ }^{32}$

A final complication was uncertainty over the position of dockers in the coming upheaval. ${ }^{33}$ A strong tradition of joint action existed at the waterfront, but in I9I I the NSFU could not obtain promises of support

which was some 1 20,000 strong; Marsh and Ryan, The Seamen, p. 306; B.P.P 191 2-191 3, Return of the Number, Ages, Ratings and Nationalities of the Seamen Employed on 3rd April I9I I, on Vessels Registered in the British Islands, [Cd 6442].

29. Wilson to Jochade, 9 February I 9 I I, MRC, MSS. I 59/3/B/63/r. See also E. Tupper, Seamen's Torch (London, 1958), pp. 16-20.

30. Among its difficulties were very high administrative costs in relation to income, which stemmed from the need to retain large numbers of full-time officials, and a high level of financial uncertainty, due to the mobility of its members and their uncertain status while out of contact with the union ashore; Lindop, "Seamen's Trade Unionism to I929", pp. 64-65.

3i. The extent of the NSFU's indebtedness was revealed by financial records released subsequently. On I January I9I I the NSFU owed $£_{4,985}$ I 4 s 6 d; Southampton Times, I 3 July I9I 2; British Seafarer, August I9I 2.

32. Brooker, Hull Strikes of I9I I, p. I 3. In taking this position, Hull Trades Council may have been seeking to avoid entanglement in the ongoing rivalry between the NSFU and the local Hull Seamen's Union.

33. This said, the international strike was conceived from the outset specifically as seamen's movement rather than a joint campaign. This may reflect Andrew Furuseth's concern with the question of the seamen's (unique) legal status, coupled with suspicion of shore-based unions borne of domestic jurisdictional disputes; see Weintraub, Andrew Furuseth, pp. 78-84. 
from the dockers' leaders. Tillett's DWRGLU had its attention focused on London, where a new wage claim was submitted during April I9 I I. ${ }^{34}$ The NUDL, under the cautious leadership of James Sexton, was even less inclined to commit to the NSFU's ambitious schemes. The National Transport Workers' Federation, which had been formed the previous year and had been heralded as a symbol of growing unity, announced its decision not to support the strikes on 9 June, underlining the apparent isolation of the seamen. ${ }^{35}$

In view of the institutional weaknesses outlined above, which contrasted so markedly with the resources and organizational sophistication of the Shipping Federation, some labour observers greeted plans for strike action with scepticism. In Britain, Robert Williams of the NTWF described the seamen's strike later as "a gambler's last chance", promoted by a union that was "on it last legs". ${ }^{36}$ There was also criticism from leading figures in the ITF, notably the German seamen's leader Paul Müller, who considered the proposed international strike to be reckless and unrealistic, and who urged the NSFU and other interested parties to devote more attention to practical union-building. ${ }^{37}$ But the latter was more easily said than done, given the union's lack of resources, the lack of recent successes to drive recruitment, and the strong likelihood that any conspicuous progress would trigger intervention by the Shipping Federation. Only an upsurge on a massive scale could realistically hope to tie up the Federation's strikebreaking machinery and prevent exploitation of local weaknesses, while simultaneously prompting a dramatic breakthrough in morale, recruitment and, consequently, funding.

\section{PRE-STRIKE PREPARATIONS AND ORGANIZATION IN GLASGOW}

In the early years of the twentieth century, Glasgow was one of the principal centres of British shipping. Official records show 3,75 I foreign and home trade vessels equalling 6,919,3 I0 net tons using the port in I910, along with 17,373 coast-wise vessels totalling $3, \mathrm{I} 28,360$ net tons. ${ }^{38}$

34. Lovell, Stevedores and Dockers, p. I 54.

35. The Times, ro June i9i I.

36. Williams's report in "I.T.F. Reports of the Organisations", (Berlin I913), quoted in Mogridge, "Militancy and Inter-Union Rivalries", p. $38 \mathrm{I}$.

37. The German seamen's leader, Paul Müller, and the ITF's president, Herman Jochade, both harboured serious concerns about the strike scheme. Müller wrote extremely critical pieces for his union's journal; Wilson to Jochade, I7 July I910, MSS.159/3/B/63/r; The Times, 29 August I910. Jochade provided invaluable assistance to the campaign, despite his misgivings, which he expressed privately to Wilson, Furuseth, and other interested parties. Golding explores the general differences in approach underlying these differences on the question of the international strike in "International Transport Workers", pp 68, 98, I 22-I 25.

38. Annual Statement of Shipping and Navigation of the UK, I9IO. 
Glasgow was placed fifth among UK ports in terms of cargo handled, and dominated Scottish shipping by a large margin. Only approximate measures can be given of the (clearly very large) numbers employed at the docks and on board Glasgow-based ships. Three to four thousand merchant seamen signed on foreign-going ships at Glasgow each month. This accounted for a little over 8 per cent of foreign-going engagements made in UK ports. ${ }^{39}$ The number of individual seafarers (the above figures count sailings and exclude the large number of seamen on home trade and coasting vessels) cannot be determined with precision, but a useful indication is provided by estimates made in connection with the strikes themselves. Strike organizers placed the number of seamen gaining wage increases following the strikes at 7,268 while the Shipping Federation estimated $9,950.4^{\circ}$ The number of dockers was placed at 8,450 men in the afore-mentioned union estimates and at the strikingly similar figure of 8,370 at the time of the Shaw inquiry in $1919 .{ }^{41}$

This large waterfront workforce was occupied in a wide range of distinct trades and services. Glasgow was the archetypal "general port", notable for the sheer breadth and variety of its shipping activities..$^{42}$ Much of its shipping was tied to manufacturing activities, but it was also a key centre for commerce, distribution, and communications. The greater part of its trade was carried on within Scotland itself and with nearby Ireland, yet few ports could match the range and development of its international connections. Significant trades requiring specialized facilities included coal export and the iron ore, grain, timber, and livestock import trades. Passenger and mail liners were also prominent, as Glasgow had longstanding imperial connections and was a major port of departure for ships conveying emigrants to North America. The port's diversity shaped the development of the strikes there, as the position and attitudes of workers and employers varied considerably between sectors.

Despite this variety, Glasgow's waterfront workers were characterized more by concentration than fragmentation, not only among dockers but also seafarers. In some other major ports, trade was carried on principally by large numbers of small vessels operating to an itinerant "tramp-ship"

\footnotetext{
39. Board of Trade Labour Gazette, I910-I9I I.

40. Forward, is July igi i; Southampton Times, is July i9i I.

4I. Forward, is July I9I I. This figure is strikingly similar to the 8,370 dockers recorded by Glasgow representatives to the Shaw inquiry into dockers' wages in 1919; Table reproduced in Kenefick, Rebellious and Contrary, p. 71.

42. The ports of South Wales and, to a lesser extent, north-east England, were dominated comprehensively by coal, while at the other end of the spectrum the rapidly emerging port of Southampton rested almost entirely on mail and passenger transport. For Glasgow's shipping industry see J.F. Riddell, Clyde Navigation (Edinburgh, 1979); Gordon Jackson and Charles Munn, "Trade, Commerce and Finance", in W. Hamish Fraser and Irene Maver (eds), Glasgow, II: I830-I9I2 (Manchester, I996), pp. 52-96; Kenefick, Rebellious and Contrary, pp. 56-79; Gordon Jackson, History and Archaeology of Ports (Kingswood, 1983).
} 
pattern. This tended to produce a highly dispersed and transient seafaring workforce, as exemplified by the port of Cardiff. ${ }^{3}$ Glasgow had its share of tramps, but vessels belonging to resident firms and operating to fixed schedules accounted for the bulk of employment. This kind of shipping provided opportunities for regular employment and tended to promote local residence and stability within the workforce. ${ }^{44}$ Seamen were brought together as part of large crews and company workforces. In Glasgow, three ocean-liner firms, the Anchor, Allan, and Donaldson lines, employed nearly 4,000 sailors, firemen, and stewards between them..${ }^{45}$ Short-distance coasting and cross-channel services, operated by such firms as G. \& J. Burns, Langlands, and the Clyde Shipping Company also made considerable contributions. Crews ranged from just under I00 to more than 250 aboard the ocean liners, which were quite small by the standards of the sector, and from 20 to 40 on home trade vessels. ${ }^{46}$ Clearly we are not dealing here with a mass of atomized itinerant workers, as seafarers are sometimes assumed to have been, but with relatively stable groups composed of sizeable units.

The distribution of employment among the dockers was a little different in that tramps, coastal shipping, and home trade services employed more dockers than the ocean liner firms, accounting for perhaps as much as twothirds of the workforce. 47 But this was merely a different pattern of distribution, for the tendency for workers to be brought together as part of the work process was just as pronounced. Operations were separated physically, with coasting vessels using the eastern end of the port and larger ships taking up the western portions of the harbour. ${ }^{4}$ Both sectors brought dockers into close proximity with each other, however, and the port was extremely compact overall, certainly in comparison with the sprawling dock complexes of London and Liverpool. One other notable factor is the preponderance of the Catholic Irish among Glasgow's dockers, which seems to have provided a strong cultural, ethnic, and community underpinning for collective action. ${ }^{49}$

43. Daunton, "Inter-Union Relations on the Waterfront"; idem, "Jack Ashore: Seamen in Cardiff Before I914", Welsh History Review, 9 (1978), pp. 176-203; Tupper, Seamen's Torch, passim. 44. Work patterns and local residence among seafarers are explored in Matt Vaughan Wilson, "The Seafarers of Southampton and Glasgow: Collective Action and Combination, 1910-1929", (unpublished Ph.D. thesis, University of Birmingham, 2006) and also in V.C. Burton, "The Work and Home Life of Seafarers - With Special Reference to the Port of Southampton, I87 II92 I", (unpublished Ph.D. thesis, University of London, I988); Sari Anita Mäenpää, "New Maritime Labour?: Catering Personnel on British Passenger Liners, I860-1938", (unpublished Ph.D. thesis, University of Liverpool, 2002).

45. Forward, is July i9i i.

46. Examples of crew sizes on a representative range of Glasgow vessels can be found in Vaughan Wilson, "The Seafarers of Southampton and Glasgow", p. 57.

47. Kenefick, Rebellious and Contrary, p. 71.

48. Sir David J. Owen, Ports of the United Kingdom (London, I948, $2^{\text {nd }}$ edn), p. 289.

49. Kenefick, Rebellious and Contrary, pp. 2 I-25, I I2-I 24. 
The situation among seafarers was more complex, but perhaps not entirely dissimilar. Havelock Wilson once noted inter alia that most of the men on the short-sea boats were from the Scottish Highlands. ${ }^{\circ}$ If so, a shared background as immigrants from rural, mostly Catholic areas may have helped to cement ties between the dockers and the seamen. More broadly, there is evidence of strong family, workplace, and community ties within the seafaring workforce, particularly in the ocean liner section. ${ }^{5 \mathrm{I}}$

The factors outlined above rendered Glasgow fairly conducive to the rapid spread of strike action within the waterfront labour force. However, other local characteristics posed general problems for strikers and for trade unionism, particularly over the longer term. Glasgow firms had large agricultural areas and fishing communities in nearby Ireland and West Scotland from which to recruit strikebreakers. ${ }^{52}$ The volatility of the local economy and labour market was also problematic. The key local industries of shipbuilding and engineering industries were subject to extreme cyclical fluctuations in activity which caused periodic bouts of severe city-wide unemployment. Glasgow waterfront workers suffered the effects of these localized slumps in addition to that of general downturns in the shipping industry. Such depressions seriously hampered efforts to maintain levels of organization developed in more prosperous periods.

Glasgow was an important centre of trade-union development among seamen and dockers before I9I. The NSFU established a branch there very early in its nationwide expansion, built up a large local membership during I 888, and fought two major strikes in I 889.53 Organization among dockers had an even longer history, which included the establishment in I 853 of the Glasgow Harbour Labourers' Union. The GHLU developed among ship-workers, a relatively more skilled and exclusive section of the workforce than quayside labourers, and achieved peak membership figures of 900 in I 872 and 1,000 in I 892.54 The formation of the National Union of

50. Wilson to Mann, 20 June I9I I, reproduced in Taplin, Near to Revolution, pp. 87-89, 89. 5. Vaughan Wilson, "Seafarers of Southampton and Glasgow"; Burton, "Work and Home Life of Seafarers”; Mäenpää, "New Maritime Labour?”.

52. The availability of fishermen from North Sea communities was particularly significant in providing a source of men with enough seagoing experience to be entrusted with a vessel at sea. Edward Tupper noted the difficulties this posed for Glasgow seamen up to I9I I in Seamen's Torch, p. 76 .

53. In his memoirs, My Stormy Voyage Through Life (London, I925), pp.109, I34, Wilson recalled establishing the union in July I 887 and having a branch in Glasgow formed by October or November that year. In 1889 , the Glasgow branch reported a membership of 7,500 seamen and firemen in Glasgow Trades Council Annual Report, I888-i889. Two strikes took place that year, which can be tracked in The Times, 9 January-19 February and 5 June-I 3 July i 889.

54. Much of this union's history is shadowy, and it is unclear even if its existence was continuous. During I889-I893 it was involved in helping to break strikes organized by the newly formed National Union of Dock Labourers. Kenefick posits that the society may have been revived for this purpose. Yet despite both its semi-artisanal origins and its later involvement in strike-breaking, the GHLU was successfully amalgamated with the newer quay-workers' 
Dock Labourers in I889, a more general and expansive union than the GHLU, inaugurated a new phase of dockers' unionism at Glasgow. It had repercussions far beyond Clydeside, for the union spread widely and established itself as the more northerly of the two major dockers' unions.

The subsequent decline of waterfront trade unionism as a national force was mirrored at a local level, although unevenly. Around I890, the Glasgow branch of the NSFU suffered a damaging financial scandal, and although it did not collapse, its fortunes fluctuated in the years that followed.5s The national leadership seems to have been held in very low esteem by sections of the Glasgow labour movement by igri. The dockers' organizer, J. O'Connor Kessack, for example, welcomed the international seamen's strike campaign as a sign that the union was "beginning to rectify its mistakes", having not been "an active and vital part of the working class movement" in the recent past. ${ }^{56}$ Similarly, the labour fortnightly Forward lamented that "no-one who is even distantly acquainted with the methods, struggles, and dangers of working-class organisations in Britain to-day, can feel satisfied with the structure of the Seamen's Union and its headquarters personell [sic]", but urged its readers to support the seamen's movement despite these shortcomings. ${ }^{57}$ The NSFU's Executive took a number of steps to reinforce its Glasgow branch ahead of the strikes contemplated for I9I I. A new Branch Secretary was appointed in May I 9I I and, at around the same time, a number of delegates to Glasgow Trades Council were coopted as members of a putative Seamen's Strike Committee..$^{8}$

During 1909-I9I I, seafarer trade unionism was bolstered from another angle, as a strong union began to emerge among marine catering workers. These workers were the fastest growing section of the seafaring workforce, accounting for one in five seafarers nationally, and rather more in ports with large passenger trades such as Glasgow.99 The National Union of Ship's Stewards, Cooks, Butchers, and Bakers was founded in Liverpool in I909 and established branches in Southampton and Glasgow during I910. ${ }^{60}$ The NSFU welcomed its emergence and included it in preparations for the seamen's strike, which the new union in turn promoted

union, the NUDL, in 1899 . For an overview, see Kenefick, Rebellious and Contrary, pp. I $67-180$.

55. Glasgow Trades Council Annual Report, I890-1891 and passim. There is little to indicate the state of the local branch over this period. The local branch was not affiliated to the Trades and Labour Council in I894-I895, I899-1900, or 1909-1910, suggesting a lack of funds or activity. In $1908-1909$ the branch made contributions commensurate with a membership of around 300 to 400 , but at other times recorded a membership over 2,000.

56. Forward, 8 April i9i I.

57. Forward, is July i9i I.

58. Glasgow Herald, 20 and 24 May i9i r.

59. Mäenpää, “New Maritime Labour?”, p. 27.

60. The Union Magazine, April igro. 
enthusiastically among its own constituency. ${ }^{61}$ If the statements of its local secretary are to be believed, it already had 4,500 members in Glasgow by June I9II. ${ }^{62}$ Reports on Glasgow published in the Stewards' Union's national journal present a picture of a vigorous young organization with a strong local base aboard the liners.

Dockers' unionism seems to have held up much better than seamen's unionism during the r 890 s. Kenefick notes the NUDL's expansion from one branch to two between I 889 and I 895 , a strike involving I,200 men in I 899 and a membership of 3,500 in the same year. ${ }^{63}$ Thereafter, however, it experienced serious difficulties, leading ultimately to the dissolution of the NUDL's local branch in February i 9 I I. ${ }^{64}$ This left local dockers without any union representation as such, although Glasgow Trades Council took a characteristically proactive approach and formed a subcommittee charged with reorganizing the workforce. ${ }^{65}$ The underlying potential for organization was stronger in any case than it first appeared. The NUDL's position on Clydeside had been undermined by a number of quite specific factors, including unfavourable economic conditions, particularly during 1907-1909, and also a loss of rank-and-file confidence in the union's Liverpool-based leadership.

The immediate catalyst for the branch's dissolution was the NUDL executive's refusal to sanction strikes in support of a programme of changes to working conditions put forward by Scottish district organizer J. O'Connor Kessack, a decision which sparked mass defections among Glasgow dockers. ${ }^{66}$ No alternative organization was formed at that stage, and when dockers began to strike over the summer of I9I I they initially had no institutional framework behind them other than that provided by the Trades Council and the Seamen's Strike Committee. The overlapping personnel of these bodies played a prominent role in encouraging and assisting strikes by dockers, but refused initial requests to take charge of a dockers' union while large numbers of seamen remained on strike. ${ }^{67}$ This situation underlines the role of direct rank-and-file action and informal organization as factors in the dockers' strikes. A more formal and permanent framework, in the shape of the new and independent Scottish

6I. Marine Caterer (continuation of The Union Magazine), May and June I9I I.

62. Forward, 8 July I9I I, in which a representative claimed 5,000 members, 470 of them recruited over the previous two weeks.

63. Kenefick, Rebellious and Contrary, pp. I 82, 200.

64. Glasgow Trades Council Minutes, is February i9r I.

65. Ibid.

66. Kenefick, Rebellious and Contrary, pp. 200-203.

67. Arthur French rebuffed requests to take charge of the dockers made to him by a deputation on I9 June. Joe Houghton and Emmanuel (Manny) Shinwell did likewise, though Houghton was to relent shortly thereafter; Glasgow Herald, 20 and 2I June I9I I; E. Shinwell, Conflict Without Malice (London, 1955), p. 52. 
Union of Dock Labourers (SUDL), did not take firm shape until the strikes were well underway.

The Seamen's Strike Committee appointed in advance of the strikes brought together activists from a range of backgrounds. The senior NSFU official, Albert French, was a very recent appointment and can hardly have been overly familiar with local conditions. He is described elsewhere as a former professional photographer, and given the prominence of nonseafarers among the NSFU senior leadership, we cannot safely assume that he had a seafaring background. ${ }^{68}$ Other notable figures were Trades Council delegates. Manny Shinwell represented a clothing workers' union and was president of the Trades Council. ${ }^{69}$ Joe Houghton was secretary of the Boot and Shoe Operatives' Union, while other committee members were drawn from the clerks' and postmen's societies. ${ }^{70}$ Alongside them were two local officials of the NSFU, two from the Cooks' and Stewards' Union, and two Able Seamen. ${ }^{7 \mathrm{I}}$ Another prominent figure was the French revolutionary Syndicalist, Madame Sorgue, who appeared at a number of ports to address meetings of waterfront workers but who seems to have had a special connection with Glasgow. ${ }^{72}$ The prominence of the Trades Council was very much in line with established traditions of labour organization at the waterfront in general and in Scotland in particular, where it was partly a reflection of the relative weakness and decentralized character of Scottish trade unionism..$^{73}$

Pre-strike preparations centred on seafarers. However, NSFU leaders recognized the potential need to extend stoppages more widely in some localities, if not in all. In a letter written to Tom Mann shortly after the strikes began, Wilson described the situation in Glasgow as:

68. Forward, 24 August I9I2. It was difficult to find men with substantial experience of both seafaring and union work to act as officials, since most serving seamen could acquire only limited experience of union work. Prominent "outsiders" included national organizers "Captain" Edward Tupper and Father Charles Hopkins.

69. Peter Slowe, Manny Shinwell: An Authorised Biography (London, I993); Shinwell, Conflict Without Malice; Vaughan Wilson, "Seafarers of Southampton and Glasgow".

70. Forward, I July I9 I I; Kenefick, Rebellious and Contrary; Glasgow Herald, 20 and 24 May I9I I; Shinwell, Conflict Without Malice, p. 48.

7I. It is not clear whether or not these two seamen held any official position within the union or were involved in preparations prior to the strike itself. The reports in question date from after the commencement of the strikes, but most individuals are noted as having joined the committee before that point; Forward, is July igi I.

72. For Sorgue's background and views see Forward, io June I9I I, and The Syndicalist, October 1912, which notes her involvement in Glasgow during the shipping strikes.

73. Scottish Trades Councils had historically played a more active and prominent role than in England, and had often taken the lead in attempting to organize unskilled groups such as dockers and seamen; W. Hamish Fraser, "Trades Councils in the Labour Movement in NineteenthCentury Scotland", in Ian MacDougall (ed.), Essays in Scottish Labour History (Edinburgh, 1978), pp. I-28. In addition, the National Union of Ship's Stewards had made effective use of Trades Council assistance in establishing branches on both sides of the border; Union Magazine, October 1909, April I9ı; Marine Caterer, May I9ı I. 
[...] red hot, but I have some recollection that I have had to fight in Glasgow on a good many occasions. The men are good for about Io days, then they begin to weaken and they are bad to hold, especially the men on the weekly boats who are from the Highlands. ${ }^{74}$

For this reason, and also because of the determinedly anti-union stance of local employers, whom Wilson reckoned to be "about the most stubborn brutes to fight of any in the whole U'K' [sic]", he advocated extending the fight in Glasgow "to every section of the transport trade". Carters were not brought out, as Wilson envisaged, but dockers struck in large numbers from an early stage.

\section{THE STRIKES IN GLASGOW}

The first clear indication that a strike was imminent came on I I June, when a number of men employed on six-month contracts aboard short-sea vessels gave a week's notice of their intention to cease work. Joe Cotter, president of the Cooks' and Stewards' Union, visited Glasgow the following day, reinforcing suspicions that action was imminent. ${ }^{75}$ The beginning of the strike, on I4 June, was declared at mass meetings across the city chaired by members of the seamen's strike committee. In the main, the demands outlined at these meetings were those around which the union's prior agitation had been based: conciliation boards, an improved manning scale and better forecastle accommodation, standard rates of pay and the abolition of pay notes. Increased wages, which the NSFU had generally played down in its pre-strike campaign, were demanded at the level of $£ 5$ IOs a month for seamen on foreign-going liners, an advance of around $£_{\text {I I }}$ os on existing rates, and $£_{\text {I I }} s$ a week for weekly-paid men, an average advance of $6 \mathrm{~s}$ a week. ${ }^{6}$

Some effects of the strike were felt almost immediately. By the end of its first day the crews of several short-sea vessels had received and accepted increases. ${ }^{77}$ At least six other vessels had crews on strike, though in each case the ships concerned were able to get away short-handed or with replacements. At this stage of the strike, attention was focused on the transatlantic sailings scheduled for that weekend, which would provide an important indication of the strength of support for the movement among seamen. In the event, none of the three liners scheduled to sail were able to secure a full crew in the harbour itself, and only one was able to obtain a

\footnotetext{
74. Cited in Taplin, Near to Revolution, p. 89.

75. Glasgow Herald, I 3 June г9г г. The date of the strike had not been disclosed in advance, though many observers had correctly identified mid-June as the most likely date.

76. Glasgow Herald, is June i9i i. Weekly-paid seamen received higher monetary wages than the monthly men on longer voyages, but they had to find their own food. With this taken into account, foreign-going seamen were better recompensed.
}

77. Glasgow News, i6 June i9i I. 
replacement non-union crew. ${ }^{78}$ The two companies whose ships were held up responded by agreeing to pay the $\mathfrak{L}_{5}$ Ios a month in the case of those vessels, but since they would not agree to pay the higher rate on a permanent basis or to recognize the union, the victory was only a temporary one. Three West Highland companies, Macbrayne, M'Callum, and Orme \& Co., also made one-off concessions in order to avoid disruption to scheduled sailings..$^{79}$

Dockers soon began striking alongside the seamen, though at first in very limited numbers. On the first day of action, dockers employed by the Irish-trading Laird Line downed tools rather than work steam winches, a duty ordinarily performed by sailors. ${ }^{80}$ Then, on Friday i 9 June, labourers employed at the coasting berths struck in support of a demand for an extra Id per hour. One of the firms affected, the Clyde Shipping Company, reached a temporary arrangement with its men and secured a resumption of work. Another, G. \& J. Burns, refused to compromise, and instead replaced dockers with its own office staff. Sympathetic action began to spread more widely later that day, as various groups of maintenance workers employed by the Allan Line downed tools in sympathy with the company's seamen and firemen. ${ }^{8 \mathrm{I}}$ The dockers of the Allan and Anchor lines stopped work the following day, putting forward wage demands of their own. These events, involving the sizeable workforces of two large ocean-liner companies, marked a significant extension of the strikes. In Greenock, where Glasgow ocean liners embarked their crews and passengers, the tugboat operators who manoeuvred the vessels into position also struck, strengthening the stoppage in the liner trades still further. ${ }^{82}$

The processes through which strike action spread during this early phase of the movement are difficult to track. Much of the time, dockers and shore-workers appear to have taken the initiative themselves in linking up with the seamen's strikes. But the spread of the strikes to dockers was in line with the NSFU leadership's strategy for Glasgow. ${ }^{83}$ Strike organizers in Glasgow may well have been influenced as much by the mood of local dockers as by Wilson's advice to extend the fight across the transport sector. Whatever the inspiration, however, they began advocating a general dock strike at mass meetings across Glasgow on 20 June. The development of such as strike was not impeded, as it was in some other ports, by the reluctance of dockers' union leaders to permit a wide extension of the

78. Glasgow Herald, I6 June I9 I I. The single successful vessel was the Anchor Line's Furnessia.

79. Evening Citizen, i9 June I9I I.

80. Evening Citizen, I6 June r9r I.

8I. Glasgow Herald, 20 June I9I I. These men are described as being part of "shore squads" who took charge of vessels between voyages.

82. Glasgow Herald, 2 I June I9I I.

83. Wilson to Mann, 20 June I9I I, reproduced in Taplin, Near to Revolution, pp. 87-89. 
conflict, since the dockers had no union leaders as such. The critical factor was the attitude of the rank and file.

By the second weekend of strike action, trade at Glasgow harbour was largely paralysed ${ }^{84}$ Local employers had already taken various steps to combat the movement. In the early stages of the dispute the Shipping Federation secured and equipped a depot ship with accommodation for 50 to Io० men, which was stationed off the Firth of Clyde near Greenock and played an important role in blacklegging operations. ${ }^{85}$ The Allan Line, which, like its fellow two ocean liner companies and most of their counterparts in other ports was not affiliated to the Shipping Federation, fitted out one of its own ships for the same purpose, but made no use of it. ${ }^{86}$ Instead, it offered a settlement on 2 I June which comprised a wage increase of $£_{I}$ a month together with recognition of the union. There was apparently some desire, both among the men and some members of the strike committee, to press the company further on wages. However, Wilson, who was contacted for advice, recommended the agreement as acceptable, in view of the fact that recognition had been granted. ${ }^{87}$ Local leaders endorsed this position, which was accepted at a mass meeting of the seamen concerned. The Allan line's fellow liner firms, Anchor and Donaldson, quickly moved to make agreements on the same basis. ${ }^{88}$

The rapid capitulation of these three powerful firms surprised many. Yet despite their size and financial strength, these firms were badly placed to withstand widespread or prolonged stoppages. Their overheads and fixed capital costs were high, and during the course of any dispute they incurred fines for non-compliance with the terms of their mail contracts, plus the expense of feeding and accommodating passengers. Very large numbers of substitutes were required even to form a skeleton crew for a large liner, which greatly reduced the potential for breaking strikes by importing labour. Finally, intense competition among passenger liners placed pressure on employers to make terms with the unions rather than lose custom to rival firms. These accumulated difficulties led one Glasgow newspaper to declare that the liner firms were "to a large extent helpless in the matter". 89 The situation proved much the same in Liverpool, where, as

\footnotetext{
84. Evening Citizen, I9 June I9I I.

85. Evening Citizen, I6 June I9I I; Glasgow News, I9 June I9I I.

86. Evening Citizen, 2 I June I9I I.

87. Glasgow Herald, 23 June I9I I; Evening Citizen, 22 June I9I I; Glasgow News, 23 June I9 I I. Shinwell later claimed to have secured the higher rate of $£ 5$ ios for the liner men, but to have been overruled by Wilson, who had already decided on acceptance of the lower figure; Shinwell, Conflict Without Malice, p. 50. There is no evidence of this in the contemporary record, however. It may be that Shinwell and other organizers, along with much of the rank and file, resented the compromise agreement and felt more could have been achieved, but that this was not acted upon. 88. Evening Citizen, 22 and 24 June I9I I.

89. Glasgow News, 23 June I9I I.
} 
Eric Taplin notes, the dominant companies were "in no position to tear up their timetables and engage in a prolonged struggle"..$^{\circ}$

Many smaller local concerns followed the liner firms' lead, and by the end of June settlements had been reached with Clan Line, City Line, and the "Swift Steamer" river boat company, each of which recognized the NSFU and granted increases averaging $3 \mathrm{~s} 6 \mathrm{~d}$ a week. Three more firms, Holt, Hutchinson, and Hogarth, made similar concessions, as did the West Highland operators. ${ }^{9^{\mathrm{I}}}$ This concluded the main phase of action among the seamen. However, six companies in the coasting and Irish trades offered stiffer resistance, as a result of which around 500 seamen remained on strike until the end of July..$^{2}$

The pattern of employers' responses revealed here deserves further comment. It has often been suggested that large liner firms were especially hostile to waterfront trade unionism and were able to resist unionization much more effectively than their smaller counterparts, thanks to the greater resources at their disposal. ${ }^{93}$ This certainly seems to have been reflected in the pattern of dockers' trade unionism prior to I9I I, for unions established substantial roots only where smaller employers prevailed. However, there were countervailing factors. Combination reduced the vulnerability of smaller firms and cargo traders which, not coincidentally, were among the most stalwart members of Shipping Federation after its formation in 1890 . The central concern of liner companies in the passenger trades was to maintain regular operations and compete effectively with rivals: while this often led them to oppose unionization more resolutely than other firms, in other circumstances this same overriding goal prompted them to lead the way in conciliating labour and attempting to work with the unions.

One other feature of this first phase was the apparent divergence of the seamen's strike from its previously advertised objectives. Wage increases, which had featured relatively little in pre-strike agitation, became increasingly prominent as a demand once the strikes were underway, while some longer-term organizational objectives, notably the much vaunted Conciliation Boards, were not put forward with great vigour. These developments led the Glasgow Herald to assert, on 2I June, that

[...] the ground has been completely shifted since the strike was declared, and instead of being a great international struggle for a "Seamen's Charter", and for

90. Taplin, Dockers' Union, p. 85 . Southampton's large liner firms conceded just as rapidly, and because of their dominance in that port's employment structure the strikes there were concluded as early 23 June; Southampton Times, 24 June i 9 I I.

91. Glasgow Herald, 27 and 30 June I9I I; Forward, is July i 9 I I; Glasgow News, 26 June I9I I. 92. The six companies concerned were the Laird Line, Clyde Shipping Company, G. \& J. Burns, William Sloan, William Robertson, and Langlands \& Co.

93. Lovell, "Sail, Steam and Emergent Dockers' Unionism”, Broeze, "Militancy and Pragmatism”, pp. $175-176$. 
the recognition of the Union by the Shipping Federation, it is a fight with individual firms, whether Federation or not, for an advance of wages. 94

Wilson lent weight to this view with his statement that the union still intended to insist on Conciliation Boards but "one job was enough at a time, and they were going in for wages first".95

Wages had not quite come to eclipse all other objectives, for union recognition was being put forward everywhere as a demand. There was, however, potential for disagreement over priorities. In the early stage of the strike, in Glasgow and elsewhere, companies were able to avoid disruption simply by granting higher wages. Wilson, surveying the situation from the centre, feared that the value of recognition and the need for "discipline" were being forgotten. On 25 June he issued a circular complaining that "in one or two instances where companies have recognised the union and I have ordered a compromise, there has been reluctance on the part of the men to carry out my instructions", and appealing for "absolute discipline" in the ranks of the movement. ${ }^{96}$

After the publication of this document, strike leaders in Glasgow redoubled their efforts to emphasize recognition as an objective. On 26 June, French told groups of strikers that "they did not want advances in wages - at least not without recognition of the union". ${ }^{97}$ Dockers were told "that it was better to get $28 \mathrm{~s}$ a week and 'recognition' than 30 s a week without 'recognition"” $9^{8}$ Greenock tugboatmen were admonished for returning to work on increased wages but without recognition. ${ }^{99}$ But recognition was demanded universally over the course of the strikes and ultimately was universally conceded. Local leaders claimed at least one case in the strikes' latter stages of employers offering substantial wage increases, guaranteed over a period of five years, on the proviso that recognition be set aside. ${ }^{100}$ This attempt was unsuccessful, and there are no indications that Glasgow waterfront workers were not prepared generally to insist on recognition as a basis for permanent settlements.

After the seamen's early victories, momentum passed to the dockers, whose actions combined to bring about the most serious disruption witnessed up to that point. The dockers' strikes were appreciably more sporadic than among the seamen. In part, this may simply reflect the different positions of the two groups. Seamen who accepted a particular settlement bound themselves for the duration of a voyage: dockers could strike much more freely and frequently, and so were well placed to engage

94. Glasgow Herald, 2 I June i9 I I.

95. Glasgow Herald, i9 June i9 I I.

96. Glasgow Herald, 26 June i9i i; The Times, 26 June i9i i.

97. Glasgow Herald, 27 June i9i I.

98. Glasgow Herald, i July i9i I.

99. Glasgow Herald, I July I9I I; Evening Citizen, I July i9ı I.

ı००. Glasgow Herald, I July i9i I. 
in the kind of intermittent wildcat action that characterized this stage of the conflict. The seamen's strike had forced ship-owners onto the defensive. Dockers were able to probe the limits of their employers' newfound willingness to conciliate, taking action on a somewhat speculative basis and progressively extending their gains.

The strikes over overtime rates that took place on 23-24 June illustrate such tendencies at work. By this stage, dockers at the deep-sea berths (working ocean liners and other foreign-going vessels) had already received increases in their basic hourly rate, but no advances on overtime rates. On 23 June, regular hands engaged by Anchor Line decided to address the overtime question, putting forward a demand for a rise from $8 \mathrm{~d}$ to Iod an hour, which was conceded after a stoppage lasting only an hour and a half. ${ }^{\text {IOI }}$ This sparked almost immediate demands for levelling up from dockers working for the Anchor Line's rival, Donaldson Brothers. To strengthen their hand, the strikers visited the berths of Glasgow's third North Atlantic company, the Allan Line, and persuaded the dockers engaged there to join them in striking. ${ }^{102}$ As seafarers had already discovered, these big firms could very quickly be brought to heel when faced with a broad stoppage, and once one of the three made terms, its rivals were not far behind.

Ongoing sympathetic action caused further disruption in this phase of the strikes. Trimmers, who had gained the concessions they desired, remained on strike until the quay-workers had settled their dispute. The Anchor and Allan Line dockers struck for a third time in support of the same group. ${ }^{103}$ Sailors and firemen on the Atlantic lines briefly re-entered the strike on 5 July, in sympathy with cooks and stewards who were seeking to improve on the increases they had made earlier in the dispute. ${ }^{104}$ As in Liverpool, the liner firms attempted to treat catering workers less generously than the sailors and firemen, but were prevented from doing so by unexpected levels of solidarity across the three departments. ${ }^{\text {IOS }}$ Such was the resonance of calls for solidarity that on a number of occasions dockers persisted in boycotting vessels crewed by non-union seamen, despite instructions to the contrary by officials of the recently formed SUDL. One ship, the Shuna, was boycotted in this way first at Rothesay Docks and later at Glasgow itself. ${ }^{106}$

These recurrent and unpredictable stoppages proved a serious irritant to employers. One complained that "when one demand is settled, the men are no sooner back to work than they are out in sympathy with some other

I0I. Glasgow Herald, 24 and 26 June I9 I I.

102. Glasgow Herald, 27 June i9i I.

103. Glasgow Herald, 5 July i9 I.

104. Evening Citizen, 5 July I9I I.

I05. Taplin, The Dockers' Union, p. 86.

ı06. Glasgow Herald, I2 and i4 July i9i I. 
body. They have no idea how to keep an agreement." ${ }^{\circ 07}$ Another told reporters that "no sooner was one demand given into than another was put forward $[. .$.$] now the leaders seemed to have no control over their own$ forces". ${ }^{108}$ There was an element of propaganda in these statements, yet they also capture the independent spirit of the workers involved in this period of the strike wave. This was occasionally problematic for officials of the emerging SUDL in their efforts to reach and maintain negotiated agreements.

During these latter stages in particular, the impression is given of an essentially uncoordinated series of disputes led by the rank and file. Looking at the strikes as a whole, however, the importance of the role played by members of the local strike committee becomes very clear. French, Shinwell, and Houghton were a constant presence on the platform at the many mass meetings held over the course of the strikes, at which objectives and agreements were decided. Coordinating picketing was another key task presided over by the strike committee. So important and extensive was this that during the first phase of the seamen's strike, the committee took out "extensive premises" near the Customs' House at Greenock in order to coordinate picketing of the ocean liners' weekend sailings. ${ }^{109}$

The strike committee also handled communications with other ports. This too was an important task. To maximize the strength of the movement in each locality, organizers required accurate information about the status of ships moving between ports, so that vessels in dispute could be boycotted. In Glasgow, this proved to be particularly crucial for seamen employed by the six coasting and cross-channel companies that resisted the strikers most determinedly. These firms were able to assemble substitute crews and get their ships to sea, but could not persuade dockers at their destination ports to unload their vessels. ${ }^{10}$ The NSFU's Albert French went so far as to claim that the victory ultimately won in this sector "was not due to the Glasgow men so much as to the dockers in Dublin, Liverpool, Cardiff, and other ports where the vessels of the Glasgow companies had been held up". ${ }^{\text {III }}$

The significance of the strike wave's broad, semi-coordinated character is underlined here. On many occasions, of course, dockers took sympathetic action with little prompting and without the sanction of union officials. The first dockers to strike in Liverpool, interestingly, were seventy nonunion men who refused to work one of G. \& J. Burns's vessels which arrived from Glasgow with a substitute crew, and who took action on their 
own initiative, against official advice. ${ }^{\mathrm{II} 2}$ On other occasions, however, the Glasgow strike committee was able to facilitate sympathetic strikes by giving advance warning by telephone to organizers in ports where locallybased ships were expected. ${ }^{113}$ One additional tactic used by the strike committee in the strikes' later stages was to issue appeals urging the public not to patronize firms which had not settled, a line of attack used particularly in the case of G. \& J. Burns's Irish steamers, which attracted a considerable of holiday passenger traffic during the summer season. ${ }^{\text {II }}$

One final feature of the strikes worth noting was the occasional outbreak of disorder. Two significant clashes took place between strikers and the police, who had been drafted into the docks in considerable numbers. On I9 June, strikers reportedly attempted to set fire to premises where work was being carried out. ${ }^{\text {Is }}$ Police charged the crowd of 5,000 to 6,000 with drawn batons, and firemen turned their hoses on the strikers, after being pelted with bottles of mineral water taken from nearby crates. Strikers stormed sheds belonging to the same company, G. \& J. Burns, on 3 July, and fought with the blacklegs inside. Once again, police charged the strikers with drawn batons, and on this occasion a number of arrests were made. ${ }^{116}$ There were more "ugly scenes" that same day as strikers broke into the premises of the Clyde Shipping Company and attempted to board a number of vessels. ${ }^{117}$ The behaviour of the police over the course of the strikes occasioned much bad feeling. ${ }^{118} \mathrm{Hull}$ and Cardiff witnessed even more serious disorder, including arson, wrecking of property and episodes akin to full-scale rioting, which were borne of mounting frustration at the persistent refusal of employers to negotiate, coupled with the heavyhanded intervention of the authorities. ${ }^{119}$ The liner firms' early concessions may, in this respect, have helped to avoid more serious and widespread clashes at the waterfront.

I I2. Taplin, The Dockers' Union, p. 87.

i 13. Glasgow Herald, 22 June i9i i.

I 4 . These appeals were couched in different terms for different audiences. Labour papers made explicit appeals to solidarity, whereas the handbills printed for general circulation emphasized instead the potential safety implications of sailing with "inexperienced" crews; Forward, is July i9i I; Glasgow News, 29 June I91 I.

I I5. Glasgow Herald, 20 June i9i I.

i 16. Glasgow Herald, 4 July i9i I.

I 17. Evening Citizen, 4 July I9 I I.

I 1 8. A mass meeting of seamen held on 27 June condemned the police for obstructing peaceful picketing and interfering with pickets and protesters. French addressed a letter of complaint to the Chief Constable on the subject and the Trades Council entered its own protest; Glasgow Herald, 28 June 19гі; Glasgow Trades Council Minutes, 2 I and 28 June I91 I.

I 19. Brooker, Hull Strikes of I9II, pp. I9-21; Leng, The Welsh Dockers, p. 58. Liverpool witnessed still more violent clashes over the summer, including several deaths. However, these occurred much later, as part of a "second wave" of unrest touched off in August by the outbreak of strikes among railwaymen and the city-wide general transport strike that followed. See Taplin, Dockers' Union, pp. 94-96; idem, Near to Revolution, pp. I4-I 5 . 
Tensions continued to simmer in Glasgow, but by Io July the situation had become less volatile. The majority of dockers were back at work and remaining at their posts. One factor at this stage was the imminence of the annual Glasgow Fair public holiday, which took place over the weekend of I5-I7 July, and which again underlines the importance of local circumstances on strike development. ${ }^{\mathrm{I} O}$ Local newspapers considered that the dockers were remaining at work because of the desire to "have some cash by the end of week" for the holiday weekend. ${ }^{21}$ For seamen, the Fair represented plentiful well-paid work as it was the occasion for a great many excursions, pleasure trips, and extra sailings. There was concern that those seamen in the coasting trades who had still not obtained concessions would be tempted back to work by this, coupled with the offer from some companies of an additional is a week. French, chairman of the Seamen's Strike Committee insisted that only 60 men had broken away, and that 300 or 400 remained on strike. ${ }^{\text {I22 }}$

Yet it seems to have been clear by this stage that resistance in this sector could not be prolonged much further. Agreements were finally reached in the closing days of July, on the basis of an increase of $2 \mathrm{~s}$ a week to 3 Is, with union recognition and promises of no victimization of strikers, but with the companies also retaining the right to engage non-union labour. ${ }^{\mathrm{I} 23}$ The wage increases achieved by this last group of seafarers were smaller than those gained by their counterparts on other short-distance services and smaller still than seafarers working on ocean liners, who were already the highest paid section of the workforce. There were similar disparities in the wage increases achieved by different groups of dockers, but significant wage differentials were a longstanding feature at the waterfront, and the overall gains were in any case very considerable.

The impact of these events on trade union strength was enormous. Prestrike agitation may have laid the groundwork, but in I9I I, as in the I 880 s, it was industrial conflict itself that "yielded the harvest of recruits" at both local and national levels. ${ }^{124}$ In August, Arthur French reported to the Trades Council that the NSFU had added over 3,000 members to its Glasgow membership and had established new branches at Greenock Harbour and Fort William. The Stewards' Union claimed 5,000 members, mostly recruited before the strikes began, though no doubt consolidated by their success. ${ }^{\mathrm{I} 5}$ The SUDL, even more dramatically, registered a

I 20. On the significance of Glasgow Fair, "the chief date in the city's leisure calendar", see Elspeth King, "Popular Culture in Glasgow", in R.A. Cage (ed.), The Working Class in Glasgow, 1750-1914 (London, I987), pp. I43-185, I57-I59.

I2 г. Evening Citizen, i July r9гі.

I22. Glasgow News i4 July I9I I.

I23. Evening Citizen, 26 and 29 July i9i i; Glasgow Herald, 29 July I9I I.

I24. Lovell, Stevedores and Dockers, p. I 4.

I25. Forward, 8 July i9i I. 
membership of 6,400 as early as October I 9 I I, and had established ports in Dundee and Ayr. ${ }^{\mathrm{I} 26}$ As the examples of the NSFU and SUDL indicate, strong unionization in Glasgow provided a springboard for developing port organization across Scotland. It also had a less direct but nonetheless important impact on the strength of organization in other nearby ports, in Ireland and Liverpool.

The general nature of these advances must be underlined. ${ }^{\mathrm{I} 27}$ High levels of union membership were established among all the major groups in all the major branches of the industry. Recognition was extracted from all employers, including those that had most vigorously resisted during the strikes. The exact implications of recognition, including such issues as the right of union representatives to go aboard ship, the status of foremen, and the employment of non-unionists, often took longer to resolve, however. Many companies regarded recognition as a temporary tactical concession and, in January I9I 2, provoked a conflict with the SUDL over gang sizes and various questions of job control. ${ }^{\mathrm{I} 28}$ However, the union survived this challenge, which precipitated the establishment of a formal port-wide structure for joint bargaining and, in this sense, strengthened the union's position. Among other things, this strike revealed the continuing strength of connections between the seamen's and dockers' unions. Local seamen took sympathetic action, supported by their Head Office officials, who recognized the episode as a critical test of strength and despatched national organizer Edward Tupper to the scene. ${ }^{22}$ Seafarers and dockers continued to be strongly organized in the decades that followed.

\section{GLASGOW IN CONTEXT}

Some aspects of Glasgow's experiences merit further comment. The structure of the local shipping industry - more particularly the presence of several very large liner firms - had considerable bearing on the way the strikes evolved. Such firms played a role in curtailing union development before I9I I, but the widespread, simultaneous strike action witnessed that summer dramatically exposed their potential vulnerability. Their rapid capitulation in the liner ports of Liverpool, Southampton, and Glasgow was a major factor in the success of the seamen's and dockers' movements overall, not merely locally. Such clear and conspicuous victories greatly boosted rank-and-file morale, inspired new groups to take action, and weakened the resolve of ship-owners.

Questions concerning organization and interaction between rank-and-

I26. Glasgow Trades Council Minutes, i6 August i9 I I, I I October I9 I; Kenefick, “A Struggle for Control”, pp. I35-136.

I27. Female catering workers were possibly an exception, though this is uncertain.

I28. Kenefick, "A Struggle for Control".

I29. Ibid.; Tupper, Seamen's Torch, pp. 74-78. 
file militancy and the strike movement's various layers of leadership also bear further attention. The proactive role of the NSFU's national leadership in the twelve months preceding the strikes stands out as very significant. Yet once the strikes were underway, they revolved principally around local forces. Activists drawn from the workforce and from other sections of the labour movement, notably Shinwell and Houghton of the Trades Council, were central to the strikes' leadership, as was the institution of the Trades Council itself. The resources available to these organizers and the strikers owed little to forces outside the city. One matter which underlined this starkly was strike pay. Neither the NSFU nor the previously unorganized dockers had accumulated funds. In the closing days of June, a union official described the ad hoc procedure adopted in Glasgow.

There had not been any payments of a definite sum each week per man. What they had been doing was to see that there was no destitution. When necessary two or three shillings a day were paid out in special cases. Then they were being approached all the time by firms for the supply of crews, and the Union officials took care to see that the men who had been longest idle got placed on these ships. In this way they saw that the strikers were supplied with funds sufficient to "keep the pot boiling". ${ }^{130}$

It has argued that the scale of industrial conflict witnessed in I9IO-I9I4 generally was largely a function of "the stage of trade union development and organization [which] made it possible to translate aspirations into action". ${ }^{\mathrm{I} I}$ This certainly does not explain the mass strikes at Glasgow Harbour, where trade union development was very much the result of massive industrial conflict rather than its precondition, and where the ability to translate aspirations into action hinged principally on the enthusiasm of the rank and file, combined with the dedicated efforts of a small number of activists drawn mostly from the local area and the workforce.

This said, Glasgow does not present a picture of a spontaneous or generally unofficial strike movement. Dockers often took the initiative in launching and extending strikes, but the actions they took aimed in the direction that the seamen's strike committee wished to pursue, developed amid much encouragement from that source and were endorsed by the committee /union officials in all but a few cases. For their part, dockers recognized the value and the position of the existing strike committee. In one revealing incident, I,, 00 dockers downed tools rather than work a ship manned by non-union seamen and promptly marched en masse to the offices of the Seamen's Union to seek the advice of the seamen's strike committee. ${ }^{132}$ 
Similarly, each of the three leading figures on the strike committee was requested by dockers to take charge of a new union. For Houghton, who accepted, this was the start of a long period at the centre of Glasgow dockers' unionism.

There are no real indications in Glasgow of the serious tension, leading to rank-and-file rebellion against recognized leaders, which marked a number of other ports. Rank-and-file attitudes may partly explain this. The significance of union recognition and other institutional advances appears to have been very deeply appreciated in Glasgow, perhaps because of the pronounced authoritarian streak exhibited by many employers, both in the past and over the strike wave itself, though employers' responses during the latter were quite mixed, as we have seen. If employer attitudes did indeed exercise such an influence it would seem to be very much in line with the broader experience of the I9I0-I9I 4 labour unrest on Clydeside. Arthur McIvor notes how, in strike after strike across the region, the demands of strikers "coalesced around the issue of union recognition and collective rights", and argues that "the achievement of formal union recognition, with bargaining rights, was considered by workers involved to be a prerequisite for sustaining material concessions won over the long term." "33 Glasgow waterfront workers in the summer of I9I I were no exception to this broader trend.

However, the unity and coherence of the strike movement also had much to do with the attitudes of the local leadership and - a related factor -the position of its dock labour force. The absence of an existing union among dockers did not prove to be a barrier to their involvement in the strikes. Rather, it contributed to the ease with which the strikes spread, as can be shown by a brief consideration of how the strikes developed in other ports.

The leaders of the major dockers' unions were not committed to the NSFU's campaign and prevaricated when faced with the enthusiasm for action engendered by the start of the seamen's strike. The NUDL and DWRGLU both had cause for caution insofar as they had accumulated funds and significant bases in particular localities, which industrial action might put at risk. ${ }^{134}$ Their responses centred on using the threat of a broader waterfront movement as a lever to extract concessions and recognition from the employers while attempting to prevent such a broad movement developing in practice. In London, where the DWRGLU had put forward a number of claims in April I9I I, the union and employers entered protracted but ultimately unsuccessful negotiations which delayed

I33. Arthur McIvor, "Were Clydeside Employers More Autocratic?: Labour Management and the 'Labour Unrest', c.1910-1914”, in Kenefick and McIvor, Roots of Red Clydeside?, pp. $4 \mathrm{I}-65,54$.

I34. See n. I3, above. 
industrial action until August. In other ports it attempted to stave off action, while the NUDL, in Liverpool, also prevaricated. As a result, seamen's strike leaders found themselves appealing to other waterfront workers over the heads of their union leaders, as Tupper did strenuously in Cardiff, or as Mann did in Liverpool, in the face of Sexton's reluctance to enter the conflict. ${ }^{135}$

Rank-and-file pressure, exercised against a reluctant leadership, played a crucial role in spreading the strikes among dockers in such circumstances. This, in turn, was a major factor in the conflicts that emerged between strike leaders and strikers over the course of the strike wave. Hull dockers repudiated the DWRGLU and developed their own leadership directly in response to the union's instruction not to cease work. ${ }^{136}$ Resentment at that union's attitude led to a bolstering of the NUDL, which was able to turn its limited presence at Goole into a significant Humberside membership base over the course of the strikes. But in Liverpool, the NUDL's main base, rank-and-file suspicion of NUDL leaders played a role in sparking rank-and-file revolts against the strike leadership. ${ }^{137}$ We can only speculate as to what would have happened had the NUDL maintained a base in Glasgow up to the summer of igir. The likelihood is that the strikes would have developed in much the same overall direction, but would have come up against the reluctance of the NUDL leadership, making rank-and-file militancy even more central to the extension of conflict.

As it was, a defining feature of Glasgow's experience was the centrality of local forces, even judged by the standards of a strike wave in which the importance of local leaders has often been remarked upon. ${ }^{13}$ The leading role played by Glasgow Trades Council and its activists, the lack of any direct intervention by prominent national officials of the seamen's union, and the absence of any outside agency organizing among the dockers underpin this sense of a movement predicated on local organization. This same feature was to characterize waterfront trade unionism at Glasgow in

I35. Daunton, "Inter-Union Relations", p. 369, Taplin, The Dockers' Union, p. I05.

I36. Brooker, Hull Strikes of I9II, p. I I.

I37. Liverpool's sheer size and complexity was perhaps also a factor, insofar as it made it difficult to coordinate a port-wide movement and encouraged a sense among some groups that their specific needs were not being adequately recognized. Dockers at Liverpool's north end, where union representation lacked firm roots, pressed to have local organizer, George Milligan, made a member of the strike committee "as one who had special knowledge of the needs of the north end dockers". He shared the north-end dockers's suspicions of Sexton's motives in urging a return to work with a partial settlement pending a further conference with the companies; Taplin, Dockers' Union, p. 9 I.

I38. Taplin notes the role played by George Milligan and other local delegates in paving the way for action at Liverpool's north end. With the exception of Cardiff, the strike committees of the south Wales ports were also formed primarily of local activists, as noted in Leng, The Welsh Dockers, p. 60. 
subsequent years. Building on a long history of dissatisfaction with the policies and personnel of the NUDL, as well as the immediate stimulus of unrest in I9I I-I9I 2, the Scottish Union of Dock Labourers built a strong bastion of independent, locally-based organization centred on Glasgow. National institutions of the labour movement viewed this development with some unease, initially at least, not wishing to encourage separatism. ${ }^{3} 39$ However, the success of the SUDL in recruiting and maintaining members cemented its position. Its appeal in Glasgow can be attributed to its strong local roots and immediate connections between leaders and the rank and file. As Kenefick describes it, it reflected "the determined desire on the part of the Glasgow dockers to shape their own independent organisation", a desire which proved persistent. ${ }^{\mathrm{I}}{ }^{\circ}$ Weakened by its involvement in sympathetic action in support of the miners during I92I, the Scottish Union joined the newly-formed Transport and General Workers' Union in I922. But attempts to "resuscitate the SUDL" were reported as early as 1923, while resistance to registration schemes brought further tensions in the later I920s. A full-scale breakaway in 1932 resulted in the creation of the Scottish Transport and General Workers' Union, which survived until I $972 .{ }^{14 \mathrm{I}}$

An independent streak was also exhibited by Glasgow's seafarers, though it proved neither as general nor persistent as among dockers. Not long after the strikes were concluded, tensions emerged in the relationship between the local branch of the NSFU and the union's Executive. In August I9I 2, senior NSFU officials unilaterally dismissed the majority of local officials and, after a brief existence as a separate "Scottish Sailors' and Firemen's Union", these officials linked up with a group in Southampton to form a Glasgow branch of the breakaway British Seafarers' Union. The concerns articulated by branch officials in this dispute involved questions of local autonomy, executive accountability, and democratic control. There were allegations of financial irresponsibility at both the centre and the locality - the latter aimed at Arthur French, now the Scottish District Secretary for the NSFU, criticism of the high salaries and expenses paid to senior officials, and calls for increased representation for Scottish branches on the Executive. ${ }^{\text {I }}{ }^{2}$

Clashes between individuals evidently played some role here too.

I39. The National Transport Workers' Federation initially refused to accept the SUDL's application for affiliation. The Glasgow branch of the NSFU urged the union's leading officials to intervene in support of the local Dockers' Union; NSFU Minute Book, I6 December I9I I. I40. Kenefick, Rebellious and Contrary, p. 2 10.

I4I. Ibid., pp. 237-243.

I42. French was alleged to have routinely charged excessive expenses in addition to his salary, not only to the Glasgow branch but to a number of others under his supervision, including Leith and Grangemouth. These allegations were reported in Forward, 24 August 19I2; Glasgow Herald, 20 August I9I 2. 
French seems to have lost the confidence of a sizeable section of the local membership while, for their part, the Liberal-Labour leaders of the NSFU were unsympathetic towards the young socialist Shinwell, who had remained active in the local branch after the strikes were concluded. ${ }^{\mathrm{I}}{ }^{43}$ Shinwell was the leading figure in the dispute with the NSFU executive and also in the breakaway union branch which resulted from it, and which organized on Clydeside until $1926 .{ }^{\mathrm{I} 44}$ Like the SUDL, this union did not represent a retreat into purely local organization - in addition to its Southampton connection it developed footholds in London, Liverpool and the Scottish port of Ardrossan. Rather, it can be regarded as a union founded principally on grassroots activism and high levels of rank-and-file participation in union affairs. It was not as comprehensively successful as the SUDL, but dominated union representation aboard Glasgow's ocean liners and obtained a strong following in other sections of local trade, in the face of stiff pressure from both the NSFU and employers. ${ }^{\text {I4 }}{ }^{25}$

As a result of these developments, the alignment of forces developed during I9I I continued to shape subsequent organization and activity. Shinwell and Houghton, drawn into waterfront organization from outside, remained at the centre of the local movement. The significance of this organizational independence was underlined on several occasions in the I920s, as waterfront labour faced a number of serious nationwide challenges. All-round reductions were made in seafarers' wage rates in I92 I, I923, and I925, with the compliance of the increasingly ship-ownerfriendly NSFU. The presence of the British Seafarers' Union and its successor organization was among the factors that made Glasgow a key centre of resistance to these impositions. ${ }^{\mathrm{I}}{ }^{6}$

Meanwhile, the SUDL distinguished itself by launching a full-scale strike in support of the coalminers during the lockout of I92 I. Other transport unions initially promised such support, but ultimately endorsed only a very limited degree of sympathetic action. This refusal to offer a

I43. The Executive's reluctance to endorse Shinwell's status was the subject of several complaints made by the branch; NSFU Minute Book, i6 December I9I I.

I44. The British Seafarers' Union amalgamated with the National Union of Ship's Stewards, Cooks, Butchers, and Bakers in I92 I to form the Amalgamated Marine Workers' Union. The latter was promoted by the National Transport Workers' Federation as a potential alternative to the NSFU, which had adopted an isolationist position within the labour movement and a superconciliatory industrial line, in the face of considerable rank-and-file pressure for a fighting policy. An overview can be found in Basil Mogridge, "Militancy and Inter-Union Rivalries in British Shipping, I9I I - 1929", International Review of Social History, 6 (I96I), pp. 375-4 I 2, and a fuller account in Vaughan Wilson, "Seafarers of Southampton and Glasgow".

I45. The NSFU made several attempts to force the BSU out of existence by forging agreements with the liner companies limiting employment to NSFU members. Such schemes proved too disruptive for the employers' liking, however, particularly since the dockers and shipbuilders' unions threatened to intervene in defence of the BSU. See Vaughan Wilson, "Seafarers of Southampton and Glasgow", pp. 237-245.

146. Ibid., pp. 266-320. 
united front, an episode which quickly earned the sobriquet "Black Friday", was not registered on the Clyde. While many other ports saw little disruption, the combination of a dockers' strike and seafarers' resistance to wage reductions engendered a second general strike at the Glasgow waterfront. ${ }^{\mathrm{I} 47}$

\section{CONCLUSION}

The strikes of I9I I stand out as the most widespread bout of industrial action witnessed at the British waterfront. Rank-and-file militancy was central to their progress. This militancy was impressive, yet perhaps not remarkable, when set against the longer-term history of waterfront labour. Seafarers and dockers had demonstrated on previous occasions, in the late I 880 s and during the I870s, their ability to take action on a significant scale, on the basis of very limited institutional development. In these instances, and also in I9I I, rank-and-file militancy was channelled into building and consolidating the unions. On later occasions, and particularly among the dockers in the post-I945 period, it often involved an explicit challenge to union leaders and policies, a change of orientation which reflected the altered relationship between workers, unions, employers, and the state. ${ }^{148}$

A propensity for militancy, often of an unofficial or semi-official character, and predicated as much on informal organization at the workplace as on formal union structures was, then, very much a feature of maritime labour. Nor was this in any sense a British peculiarity, as Frank Broeze and others have shown. ${ }^{149}$ With this in mind, it is perhaps after all the role of national union leaders which stands out as distinctive in the strikes of I9I I. Despite the limitations they faced, the leaders of the NSFU were able to develop a broad framework and a strategy for massive

I47. Ibid., pp. 266-269; Kenefick, Rebellious and Contrary, pp. 234-235.

148. Tony Topham, "The Unofficial National Docks Strike of 1923: The Transport and General Workers' Union's First Crisis”, Historical Studies in Industrial Relations, 2 (1996), pp. 27-64; Jim Phillips, "Decasualization and Disruption: Industrial Relations in the Docks, 1945-79", in Chris Wrigley (ed.), A History of British Industrial Relations, 1939-1979: Industrial Relations in a Declining Economy (Cheltenham, 1996), pp. 165-186; idem, "Inter-Union Conflict in the Docks, I954-55”, Historical Studies in Industrial Relations, I (1996), pp. 107- I 30; Fred Lindop, "Unofficial Militancy in the Royal Group of Docks, I945-67", Oral History, i I:2 (1983), pp. 2 I-33; Colin J. Davis, Waterfront Revolts: New York and London Dockworkers, 1946-6I (Urbana, IL [etc.], 2003). Rank-and-file movements also existed among the seamen in the I940sI960s, for which see Marsh and Ryan, The Seamen; A.W. Wailey, "A Storm from Liverpool: British Seamen and their Union, 1920-1970", (unpublished Ph.D. thesis, University of Liverpool, 1984).

I49. Broeze, "Militancy and Pragmatism". See also the essays in Sam Davies et al., Dock Workers: International Explorations in Comparative Labour History, 2 vols (Aldershot, 2000), especially Jessie Chisholm, "Waterfront Conflict: Dockers' Strategies and Collective Actions", pp. 709-720, which provides an overview. 
industrial action at a national and supra-national level. Their actions helped to create and maintain a sense of the strikes as a single, coordinated movement, among seamen if not among dockers.

And, while union executives faced occasional challenges over the details of the strategy to be pursued, they emerged from the summer much strengthened, at the head of organizations that enjoyed much greater influence with employers and government and were much better placed than before to exert discipline over their own members. Industrial relations in shipping were, henceforth, more formal, centralized and national in scope. But there were exceptions to the powerful tendencies towards national organization which came to characterize waterfront organization in Britain. Regional diversity, local networks and organization at the workplace continued to shape militancy at the grassroots and the internal life of the unions. Glasgow is among the ports in which such features were most pronounced. 